\title{
LEVEL II SCOUR ANALYSIS FOR BRIDGE 32 (BRIDTH00050032) on TOWN HIGHWAY 5, crossing the NORTH BRANCH OTTAUQUECHEE RIVER, BRIDGEWATER, VERMONT
}

U.S. Geological Survey

Open-File Report 96-152

Prepared in cooperation with

VERMONT AGENCY OF TRANSPORTATION

and

FEDERAL HIGHWAY ADMINISTRATION

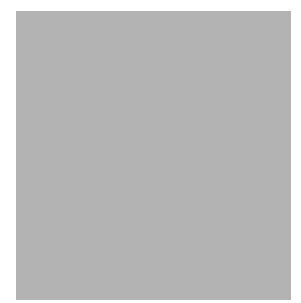




\section{LEVEL II SCOUR ANALYSIS FOR BRIDGE 32 (BRIDTH00050032) on TOWN HIGHWAY 5, crossing the NORTH BRANCH OTTAUQUECHEE RIVER, BRIDGEWATER, VERMONT \\ By SCOTT A. OLSON}

U.S. Geological Survey

Open-File Report 96-152

Prepared in cooperation with

VERMONT AGENCY OF TRANSPORTATION

and

FEDERAL HIGHWAY ADMINISTRATION 


\title{
U.S. DEPARTMENT OF THE INTERIOR BRUCE BABBITT, Secretary
}

\author{
U.S. GEOLOGICAL SURVEY \\ Gordon P. Eaton, Director
}

For additional information write to:

District Chief

U.S. Geological Survey 361 Commerce Way

Pembroke, NH 03275-3718
Copies of this report may be purchased from:

U.S. Geological Survey Earth Science Information Center Open-File Reports Section Box 25286, MS 517 Federal Center

Denver, CO 80225 


\section{CONTENTS}

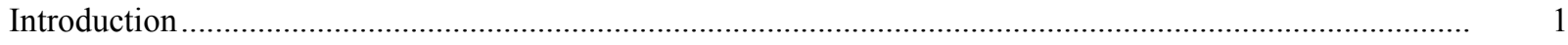

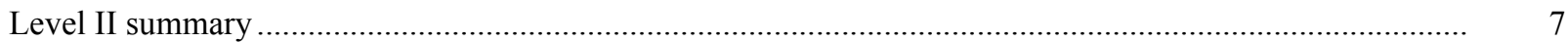

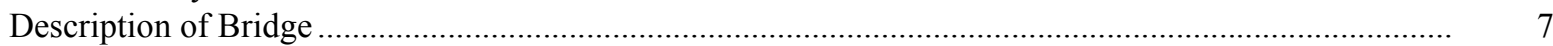

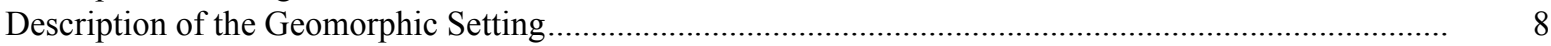

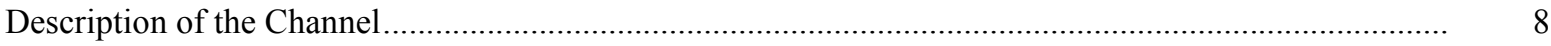

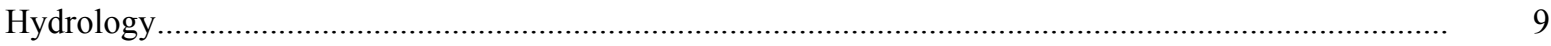

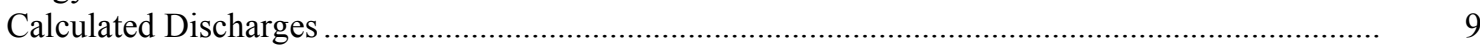

Description of the Water-Surface Profile Model (WSPRO) Analysis ......................................................... 10

Cross-Sections Used in WSPRO Analysis ......................................................................................

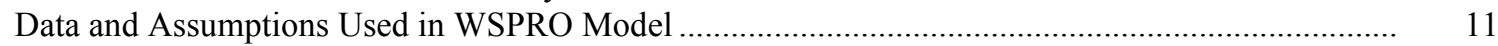

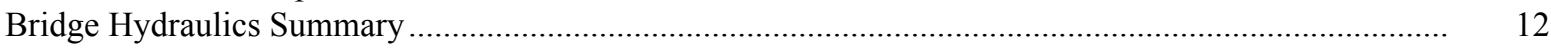

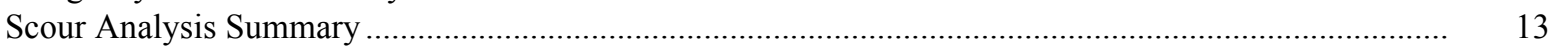

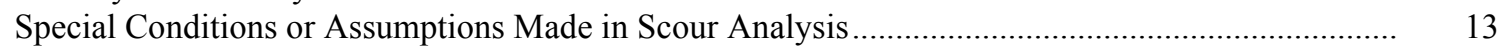

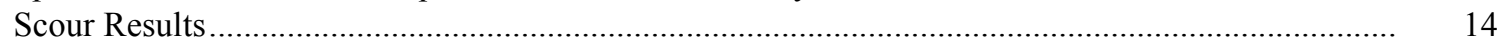

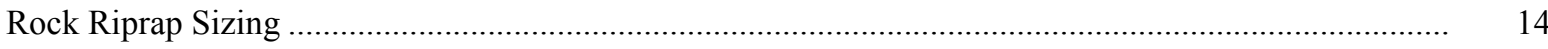

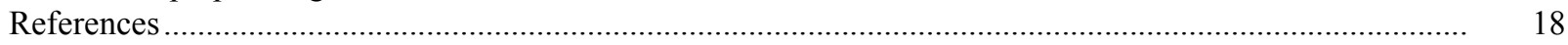

Appendixes:

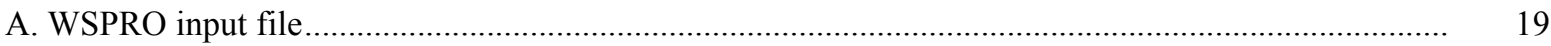

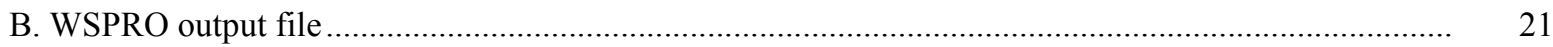

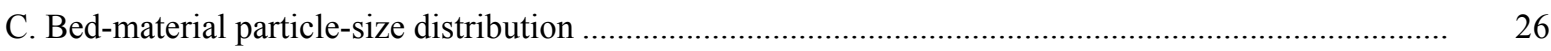

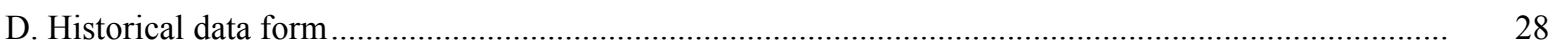

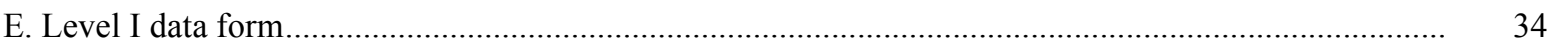

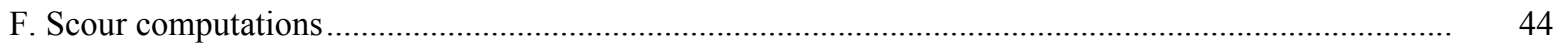

\section{FIGURES}

1. Map showing location of study area on USGS $1: 24,000$ scale map .......................................................

2. Map showing location of study area on Vermont Agency of Transportation town
highway map

3. Structure BRIDTH00050032 viewed from upstream (November 4, 1994)................................................... 5

4. Downstream channel viewed from structure BRIDTH00050032 (November 4, 1994)............................. 5

5. Upstream channel viewed from structure BRIDTH00050032 (November 4, 1994).................................... 6

6. Structure BRIDTH00050032 viewed from downstream (November 4, 1994)............................................ 6

7. Water-surface profiles for the 100- and 500-year discharges at structure

BRIDTH00050032 on Town Highway 5, crossing the North Branch Ottauquechee River,

Bridgewater, Vermont.

8. Scour elevations for the 100- and 500-year discharges at structure

BRIDTH00050032 on Town Highway 5, crossing the North Branch Ottauquechee River,

Bridgewater, Vermont.

\section{TABLES}

1. Remaining footing/pile depth at abutments for the 100-year discharge at structure

BRIDTH00050032 on Town Highway 5, crossing the North Branch Ottauquechee River,

Bridgewater, Vermont

2. Remaining footing/pile depth at abutments for the 500-year discharge at structure

BRIDTH00050032 on Town Highway 5, crossing the North Branch Ottauquechee River,

Bridgewater, Vermont. 


\begin{tabular}{|c|c|c|}
\hline Multiply & By & To obtain \\
\hline \multicolumn{3}{|c|}{ Length } \\
\hline inch (in.) & 25.4 & millimeter (mm) \\
\hline foot $(\mathrm{ft})$ & 0.3048 & $\operatorname{meter}(\mathrm{m})$ \\
\hline mile (mi) & 1.609 & kilometer (km) \\
\hline \multicolumn{3}{|c|}{ Slope } \\
\hline foot per mile ( $\mathrm{ft} / \mathrm{mi})$ & 0.1894 & meter per kilometer $(\mathrm{m} / \mathrm{km})$ \\
\hline \multicolumn{3}{|c|}{ Area } \\
\hline square mile $\left(\mathrm{mi}^{2}\right)$ & 2.590 & square kilometer $\left(\mathrm{km}^{2}\right)$ \\
\hline \multicolumn{3}{|c|}{ Volume } \\
\hline cubic foot $\left(\mathrm{ft}^{3}\right)$ & $\begin{array}{l}0.02832 \\
\text { Velocity and Flow }\end{array}$ & cubic meter $\left(\mathrm{m}^{3}\right)$ \\
\hline foot per second $(\mathrm{ft} / \mathrm{s})$ & 0.3048 & meter per second $(\mathrm{m} / \mathrm{s})$ \\
\hline cubic foot per second $\left(\mathrm{ft}^{3} / \mathrm{s}\right)$ & 0.02832 & cubic meter per second $\left(\mathrm{m}^{3} / \mathrm{s}\right)$ \\
\hline $\begin{array}{l}\text { cubic foot per second per } \\
\text { square mile } \\
{\left[\left(\mathrm{ft}^{3} / \mathrm{s}\right) / \mathrm{mi}^{2}\right]}\end{array}$ & 0.01093 & $\begin{array}{l}\text { cubic meter per } \\
\text { second per square } \\
\text { kilometer }\left[\left(\mathrm{m}^{3} / \mathrm{s}\right) / \mathrm{km}^{2}\right]\end{array}$ \\
\hline
\end{tabular}

OTHER ABBREVIATIONS

$\begin{array}{lrlr}\mathrm{BF} & \text { bank full } & \text { LWW } & \text { left wingwall } \\ \mathrm{cfs} & \text { cubic feet per second } & \text { MC } & \text { main channel } \\ \mathrm{D}_{50} & \text { median diameter of bed material } & \text { RAB } & \text { right abutment } \\ \mathrm{DS} & \text { downstream } & \text { RABUT } & \text { face of right abutment } \\ \mathrm{elev} & \text { elevation } & \text { RB } & \text { right bank } \\ \mathrm{f} / \mathrm{p} & \text { flood plain } & \text { ROB } & \text { right overbank } \\ \mathrm{ft} & \text { square feet } & \text { RWW } & \text { right wingwall } \\ \mathrm{ft} / \mathrm{ft} & \text { feet per foot } & \text { TH } & \text { town highway } \\ \mathrm{JCT} & \text { junction } & \text { UB } & \text { under bridge } \\ \mathrm{LAB} & \text { left abutment } & \text { US } & \text { upstream } \\ \mathrm{LABUT} & \text { face of left abutment } & \text { USGS } & \text { United States Geological Survey } \\ \text { LB } & \text { left bank } & \text { VTAOT Vermont Agency of Transportation } \\ \text { LOB } & \text { left overbank } & \text { WSPRO } & \text { water-surface profile model }\end{array}$

In this report, the words "right" and "left" refer to directions that would be reported by an observer facing downstream. Sea level: In this report, "sea level" refers to the National Geodetic Vertical Datum of 1929-- a geodetic datum derived from a general adjustment of the first-order level nets of the United States and Canada, formerly called Sea Level Datum of 1929.

In the appendices, the above abbreviations may be combined. For example, USLB would represent upstream left bank. 


\title{
LEVEL II SCOUR ANALYSIS FOR BRIDGE 32 (BRIDTH00050032) ON TOWN HIGHWAY 5, CROSSING THE NORTH BRANCH OTTAUQUECHEE RIVER, BRIDGEWATER, VERMONT
}

\author{
By Scott A. Olson
}

\section{INTRODUCTION}

This report provides the results of a detailed Level II analysis of scour potential at structure BRIDTH00050032 on town highway 5 crossing the North Branch Ottauquechee River, Bridgewater, Vermont (figures 1-8). A Level II study is a basic engineering analysis of the site, including a quantitative analysis of stream stability and scour (U.S. Department of Transportation, 1993). A Level I study is included in Appendix E of this report. A Level I study provides a qualitative geomorphic characterization of the study site. Information on the bridge, available from VTAOT files, was compiled prior to conducting Level I and Level II analyses and can be found in Appendix D.

The site is in the Green Mountain physiographic province of central Vermont. The 4.37-mi ${ }^{2}$ drainage area is in a predominantly rural and forested basin. In the vicinity of the study site, the US left bank is lawn; DS left bank is pasture; US right bank is shrub and brushland and the DS right bank is forested.

In the study area, the North Branch Ottauquechee River has an incised channel with a slope of approximately $0.0148 \mathrm{ft} / \mathrm{ft}$, an average channel top width of $25 \mathrm{ft}$ and an average channel depth of $9 \mathrm{ft}$. The predominant channel bed materials are gravel and cobbles $\left(\mathrm{D}_{50}\right.$ is 79.6 $\mathrm{mm}$ or $0.261 \mathrm{ft}$ ). The geomorphic assessment at the time of the Level I and Level II site visit on November 4, 1994, indicated that the reach was stable. 
The town highway 5 crossing of the North Branch Ottauquechee River is a 27-ft-long, onelane bridge consisting of one 25-foot steel-beam span with a timber deck (Vermont Agency of Transportation, written commun., August 25, 1994). The bridge is supported by vertical, concrete abutments with wingwalls. The DS left road approach is protected by type-1 stone fill (less than 12 inches). The DS right road approach is not protected and is eroded slightly by road wash. The US left bank is protected by type-2 stone fill (less than 36 inches). A stream confluence is located approximately 130 US of the bridge. The channel is skewed approximately 30 degrees to the opening. Additional details describing conditions at the site are included in the Level II Summary and Appendices D and E.

Scour depths and rock rip-rap sizes were computed using the general guidelines described in Hydraulic Engineering Circular 18 (Richardson and others, 1993). Scour depths were calculated assuming an infinite depth of erosive material and a homogeneous particle-size distribution. The scour analysis results are presented in tables 1 and 2 and a graph of the scour depths is presented in figure 8 . 


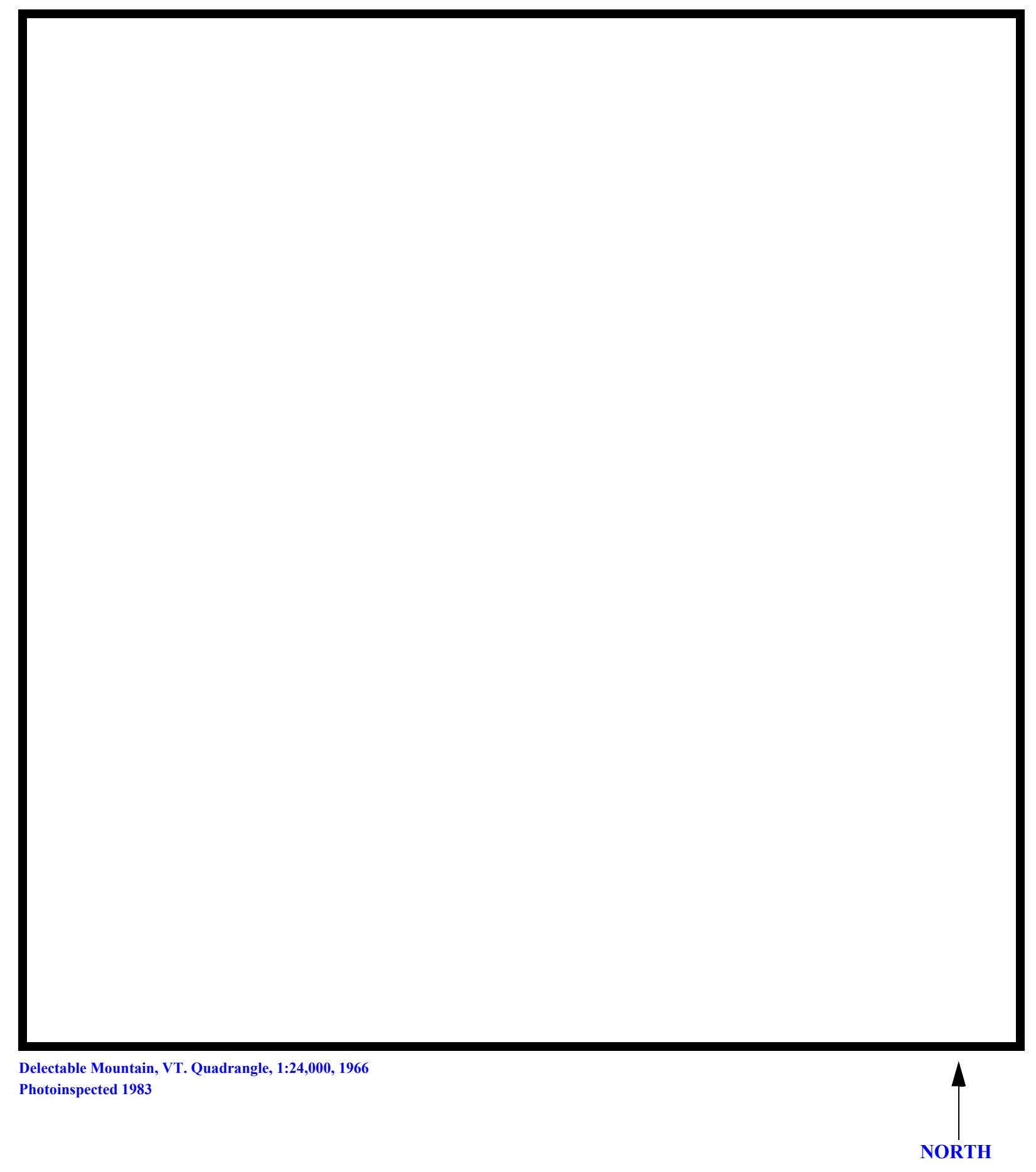

Figure 1. Location of study area on USGS 1:24,000 scale map. 
Figure 2. Location of study area on Vermont Agency of Transportation town highway map. 

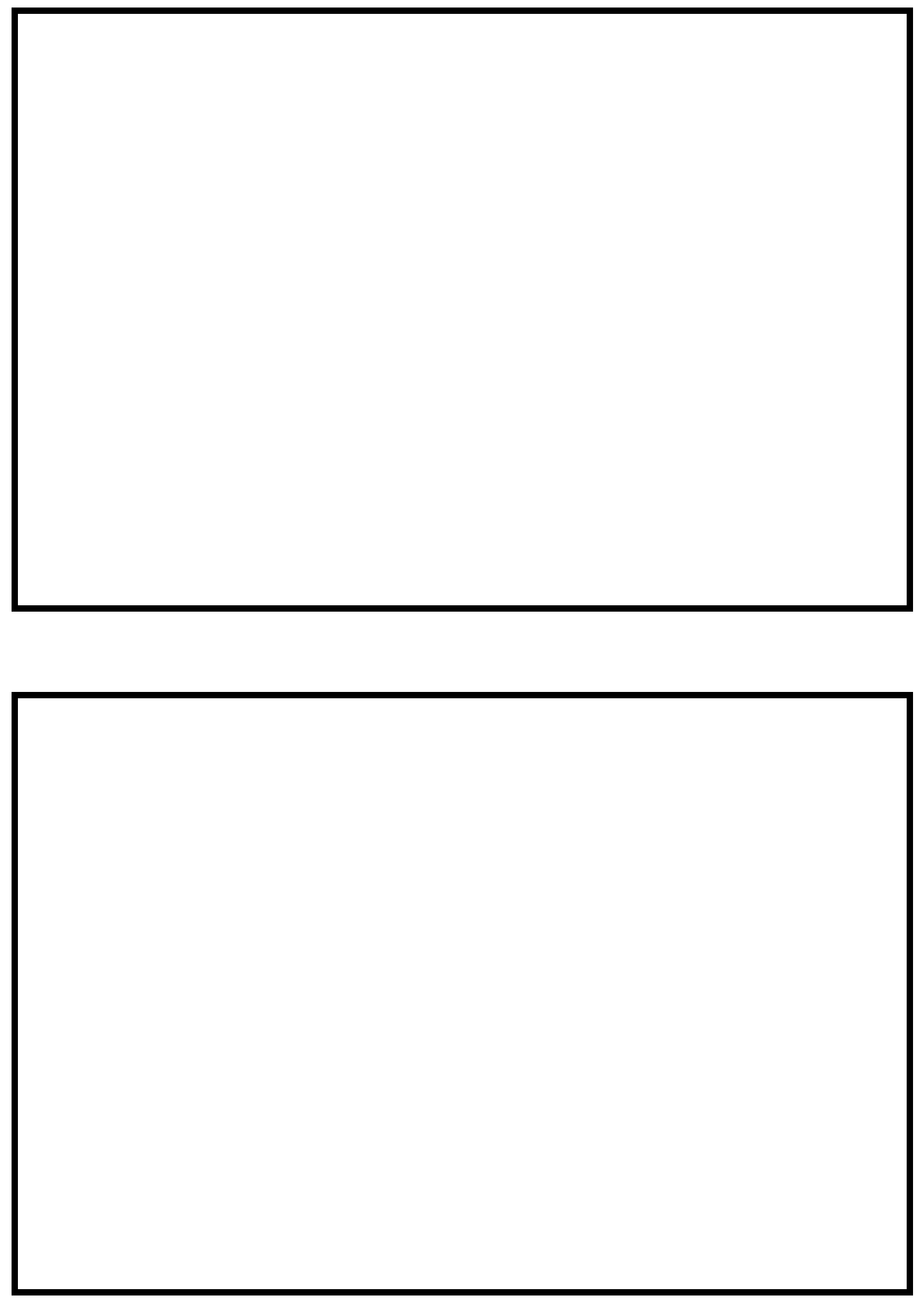

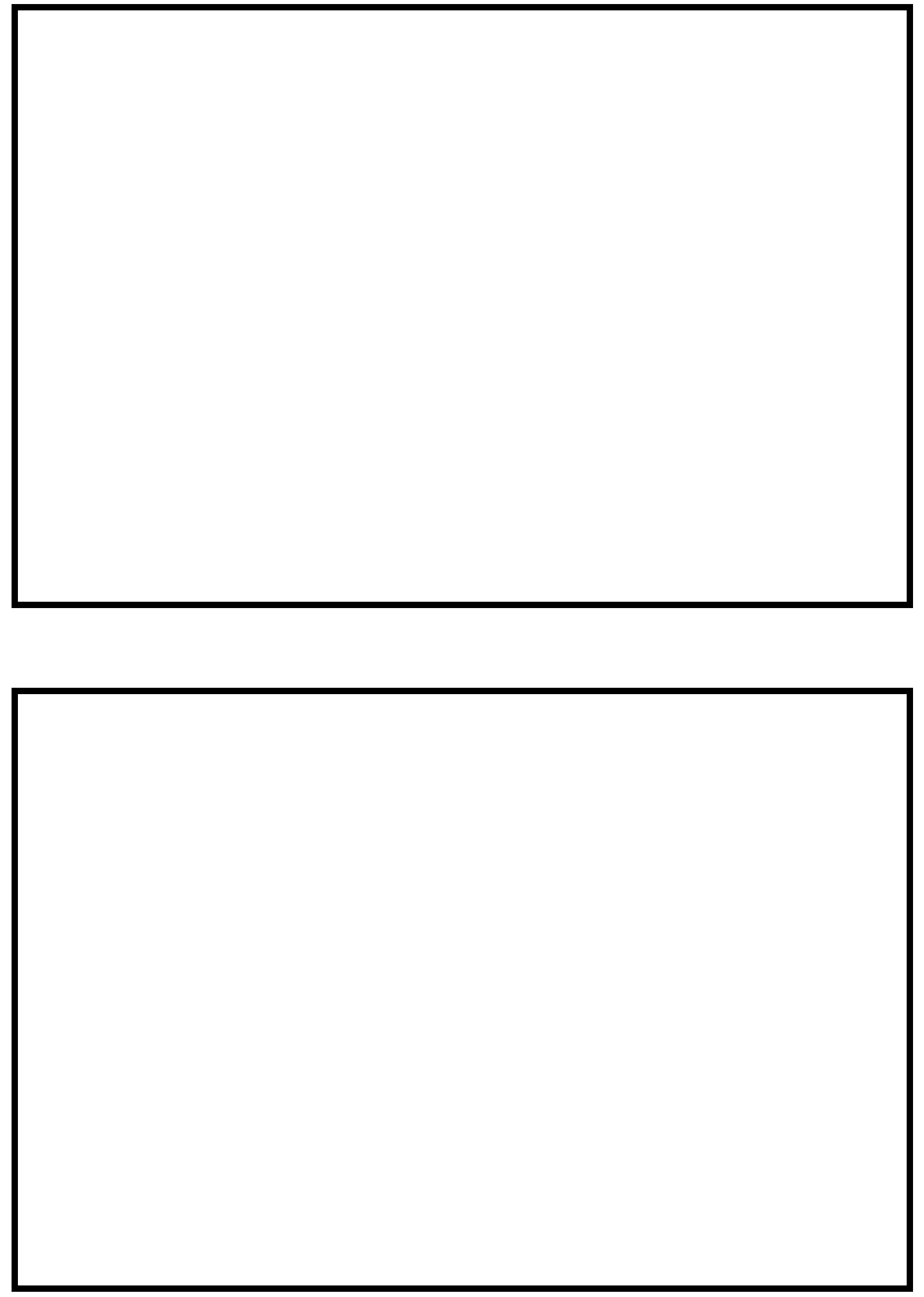


\section{LEVEL II SUMMARY}

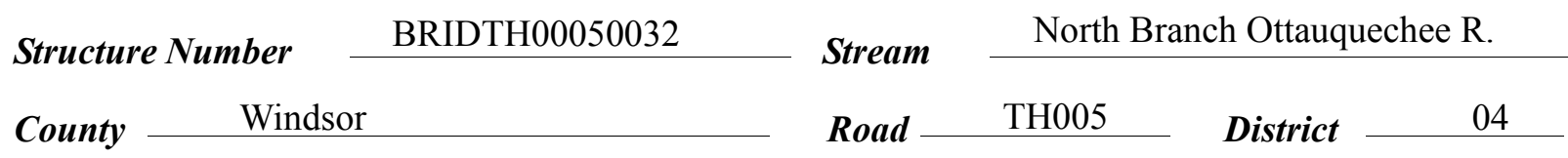

\section{Description of Bridge}

Bridge length $\frac{27}{2} \boldsymbol{f t} \quad$ Bridge width $13 \quad f t \quad$ Max span length $\stackrel{25}{f t}$ Alignment of bridge to road (on curve or straight) vertical Abutment type no

Embankment type straight

Stone fill on abutment?

nato of incnortinn sloping $11 / 04 / 94$

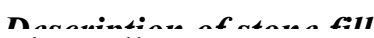
On DS left road approach,Type-1. Also, Type-2 on US and DS wingwalls.

Abutments are concrete and the left abutment is noted as having an exposed footing with approximately 1 foot of scour.

\section{Y}

Is bridge skewed to flood flow according to Y Y survey? Angle

Bridge is located on a mild bend in the channel. (Opening skew to roadway is also 30_degrees). $11 / 04 / 94$

Debris accumulation on bridge at time of Level I or Level II site visit:

\begin{tabular}{|c|c|c|c|}
\hline & $\begin{array}{c}\text { Date of insnortion } \\
\underline{0}\end{array}$ & $\begin{array}{l}\text { Percent of olhmunl } \\
\text { bloeked inortzontatly }\end{array}$ & $\begin{array}{l}\text { Percent of } 11 / 04 / \text { e } \\
\text { blocked verticatty }\end{array}$ \\
\hline & 94 & -- & -- \\
\hline & Low & & \\
\hline
\end{tabular}

Potential for debris

Doscriho anv fonturos noar ar at tho hridoo that mav, affort flow (includo ahsorvation dato). 


\section{Description of the Geomorphic Setting}

General topography The bridge is at the headwaters of the N. Br. Ottauquechee R. in a steep, upland, incised channel.

Geomorphic conditions at bridge site: downstream (DS), upstream (US)

Date of inspection $\quad 11 / 04 / 94$

DS left: $\quad$ flood plain

DS right: $\quad$ wide terrace to valley wall

US left: $\quad$ terrace to valley wall

US right: $\quad$ wide terrace to valley wall

\section{Description of the Channel}

\begin{tabular}{|c|c|c|c|c|c|}
\hline \multirow[b]{2}{*}{ Average top width } & & & \multirow[b]{2}{*}{ Average depth } & 9 & \multirow[b]{2}{*}{1} \\
\hline & $\stackrel{\boldsymbol{f t}}{\text { gravel and cobbles }}$ & & & gravel & \\
\hline Predominant bed material & & & Bank material & arrow, inc & \\
\hline channel with only slight sinuosity. & $\cdots \cdot$ & - & $\cdot \cdot$ & & \\
\hline
\end{tabular}

Vegetative col lawn and pasture

DS left: $\quad$ forest

DS right: lawn

US left: $\quad$ shrubs and brush

US right: $\quad \underline{\mathrm{N}}$

Do banks appear stable? 11/04/94--Both, the US banks are reported to have light fluvial erosion and only the left bank is protected by type-2 stone fill. Only the DS right bank is reported
date of observatton. eroded by light fluvial erosion and neither bank is protected.

11/04/94--Small rock

dam constructed to create swimming hole approx. $50 \mathrm{ft}$ DS of the bridge and $20 \mathrm{ft}$ DS of the Describe any obstructions in channel and date of observation.

EXIT cross-section. 


\section{Hydrology}

Drainage area $\quad 4.4 \quad \boldsymbol{m i}^{2}$

Percentage of drainage area in physiographic provinces: (approximate)

Physiographic province

Green Mountain
Percent of drainage area

100

Is drainage area considered rural or urban? Rural Describe any significant

urbanization: $\quad$ None. Area is mostly forested, high-elevation, headwater drainage.

Is there a USGS gage on the stream of interest?

No

\section{USGS gage description}

USGS gage number

Gage drainage area

$m i^{2}$

No

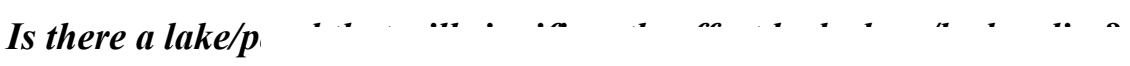

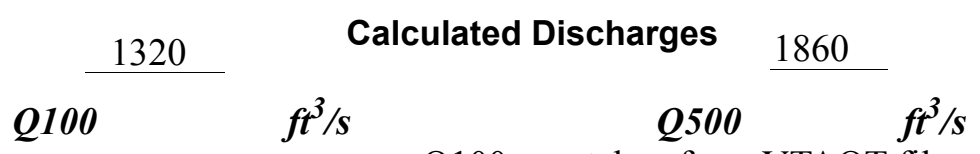

Q100 was taken from VTAOT files. Q500 was

determined by extrapolating data from empirical methods (Talbot, 1887; Potter, 1957a; Potter,

1957b; Johnson and Laraway, 1971, written commun.; Johnson and Tasker, 1974; Federal Highway Administration, 1983). 


\section{Description of the Water-Surface Profile Model (WSPRO) Analysis}

Datum for WSPRO analysis (USGS survey, sea level, VTAOT plans)

USGS survey

Datum tie between USGS survey and VTAOT plans

Add $403 \mathrm{ft}$ to USGS datum to get

VTAOT datum.

Description of reference marks used to determine USGS datum. $\quad$ RM1 is a chiseled X at

the junction between the right abutment and the US right wingwall (elev. 99.42 feet, arbitrary

datum). RM2 is a chiseled square on the DS end of the left abutment on high concrete surface

(elev. 99.54 feet, arbitrary datum).

\section{Cross-Sections Used in WSPRO Analysis}

\begin{tabular}{|c|c|c|c|}
\hline${ }^{1}$ Cross-section & $\begin{array}{c}\text { Section } \\
\text { Reference } \\
\text { Distance } \\
\text { (SRD) in feet }\end{array}$ & $\begin{array}{c}{ }^{2} \text { Cross-section } \\
\text { development }\end{array}$ & Comments \\
\hline EXITX & -33 & 1 & Exit section \\
\hline FULLV & 0 & 2 & $\begin{array}{l}\text { Downstream Full-valley } \\
\text { section (Templated from } \\
\text { EXITX) }\end{array}$ \\
\hline BRIDG & 0 & 1 & Bridge section \\
\hline RDWAY & 6 & 1 & Road Grade section \\
\hline APPRO & 65 & 1 & Approach section \\
\hline
\end{tabular}

${ }^{1}$ For location of cross-sections see plan-view sketch included with Level I field form, Appendix E. For more detail on how cross-sections were developed see WSPRO input file. 


\section{Data and Assumptions Used in WSPRO Model}

Hydraulic analyses of the reach were done by use of the Federal Highway Administration's WSPRO step-backwater computer program (Shearman and others, 1986, and Shearman, 1990). Results of the hydraulic model are presented in the Bridge Hydraulic Summary, Appendix B, and figure 7.

Channel roughness factors (Manning's " $\mathrm{n}$ ") used in the hydraulic model were estimated using field inspections at each cross section following the general guidelines described by Arcement, Jr. and Schneider (1989). Final adjustments to the values were made during the modelling of the reach. Channel " $\mathrm{n}$ " values for the reach ranged from 0.050 to 0.060 , and overbank " $\mathrm{n}$ " values ranged from 0.035 to 0.115 .

Normal depth at the exit section (EXITX) was assumed as the starting water surface. This depth was computed by use of the slope-conveyance method outlined in the User's manual for WSPRO (Shearman, 1990). The slope used was $0.0148 \mathrm{ft} / \mathrm{ft}$ which was derived from analysis of surveyed thalweg points, edge of water points and the measured channel slope from the topographic map (U.S. Geological Survey, 1966).

The modelled 100-year disharge of 1,320 cfs was also the incipient overtopping discharge. 


\section{Bridge Hydraulics Summary}

$\begin{array}{lll}\text { Average bridge embankment elevation } & 100.1 \\ \text { Average low steel elevation } & 98.0 & \boldsymbol{f t}\end{array}$

100-year discharge $\quad 1320 \quad \mathrm{ft}^{3} / \mathrm{s}$

Water-surface elevation in bridge opening $\quad 98.0 \quad f t$

Road overtopping? ___ N Discharge over road __ _ _ _. s

Area of flow in bridge opening $\quad 162 \quad \mathrm{ft}^{2}$

Average velocity in bridge opening $\quad 8.1 \quad \mathrm{ft} / \mathrm{s}$

$\begin{array}{llll}\text { Maximum WSPRO tube velocity at bridge } & 10.0 \mathrm{ft} / \mathrm{s}\end{array}$

Water-surface elevation at Approach section with bridge 99.6

Water-surface elevation at Approach section without bridge $\quad 96.7$

Amount of backwater caused by bridge $\quad 2.9$ it

500-year discharge $\quad \begin{array}{ll}1860 & \mathrm{ft}^{3} / \mathrm{s}\end{array}$

Water-surface elevation in bridge opening $\quad 98.0 \quad f t$

Road overtopping? ___ Y Discharge over road _ $321, \% / s$

Area of flow in bridge opening $\quad 162 \quad \mathrm{ft}^{2}$

Average velocity in bridge opening $\quad 9.4 \quad \mathrm{ft} / \mathrm{s}$

Maximum WSPRO tube velocity at bridge 12.2 _'s

Water-surface elevation at Approach section with bridge

100.5

Water-surface elevation at Approach section without bridge

Amount of backwater caused by bridge 3.1 .

Incipient overtopping discharge ___ -- $\mathrm{ft}^{3} / \mathrm{s}$

Water-surface elevation in bridge opening $\quad--\quad t$

Area of flow in bridge opening _ -- $\mathrm{ft}^{2}$

Average velocity in bridge opening $\quad--\quad f t / s$

Maximum WSPRO tube velocity at bridge $\quad--\quad f t / s$

Water-surface elevation at Approach section with bridge

Water-surface elevation at Approach section without bridge

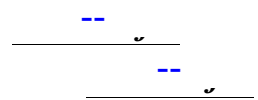

Amount of backwater caused by bridge _ $\quad-{ }_{-}$, t 


\section{Scour Analysis Summary}

\section{Special Conditions or Assumptions Made in Scour Analysis}

Scour depths were computed using the general guidelines described in Hydraulic Engineering Circular 18 (Richardson and others, 1993). Scour depths were calculated assuming an infinite depth of erosive material and a homogeneous particle-size distribution. The results of the scour analysis are presented in tables 1 and 2 and a graph of the scour depths is presented in figure 8 .

Contraction scour was computed by use of the Chang pressure-flow scour equation (Richardson and others, 1995, p. 145-146). For each of the modelled discharges, there was orifice flow at the bridge. Contraction scour at bridges with orifice flow is best estimated by use of the Chang pressure-flow scour equation (oral communication, J. Sterling Jones, October 4, 1996). The results of Laursen's clear-water contraction scour equation (Richardson and others, 1995, p. 32, equation 20) were also computed and can be found in appendix F. For contraction scour computations, the average depth in the contracted section (AREA/TOPWIDTH) is subtracted from the depth of flow computed by the scour equation (Y2) to determine the actual amount of scour.

Abutment scour was computed by use of the Froehlich equation (Richardson and others, 1993, p. 49, equation 24). The Froehlich equation gives "excessively conservative estimates of scour depths" (Richardson and others, 1993, p. 48). Variables for the Froehlich equation include the Froude number of the flow approaching the embankments, the length of the embankment blocking flow, and the depth of flow approaching the embankment less any roadway overtopping. 


\section{Scour Results}

100-yr discharge 500-yr discharge

Contraction scour:

(Scour depths in feet)

Main channel

Live-bed scour

Clear-water scour

Depth to armoring

Left overbank

Right overbank

Local scour:

Abutment scour

9.4

11.9

Left abutment

$5.8-$

7.4-

Right abutment

Pier scour

Pier 1

Pier 2

Pier 3
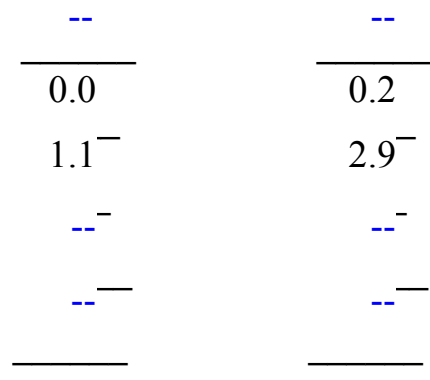

$2.9^{-}$

overtopping

discharge

Incipient$$
\text { - }
$$ 


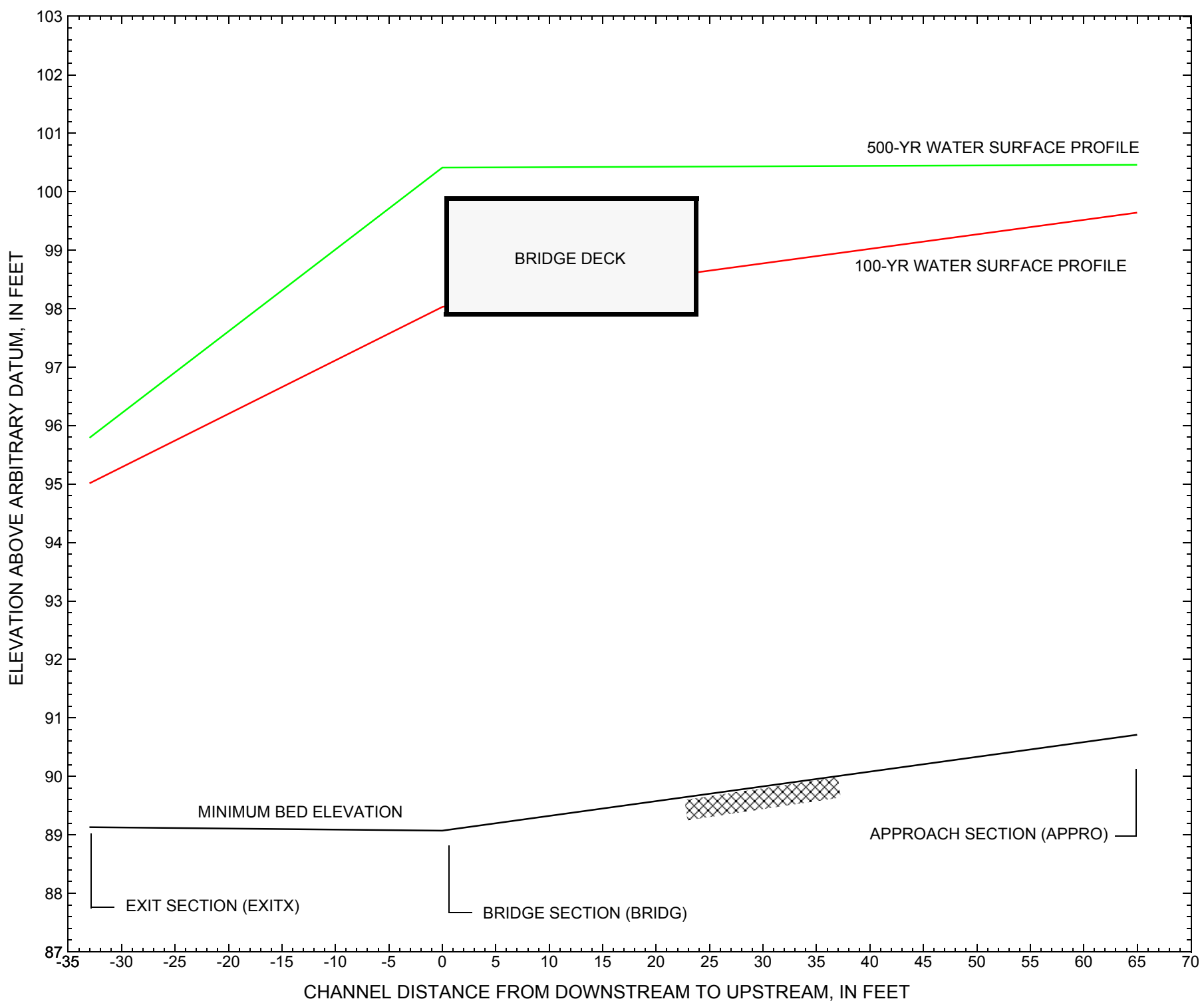

Figure 7. Water-surface profiles for the 100- and 500-yr discharges at structure BRIDTH00050032 on town highway 5, crossing the North Branch Ottauquechee River, Bridgewater, Vermont. 


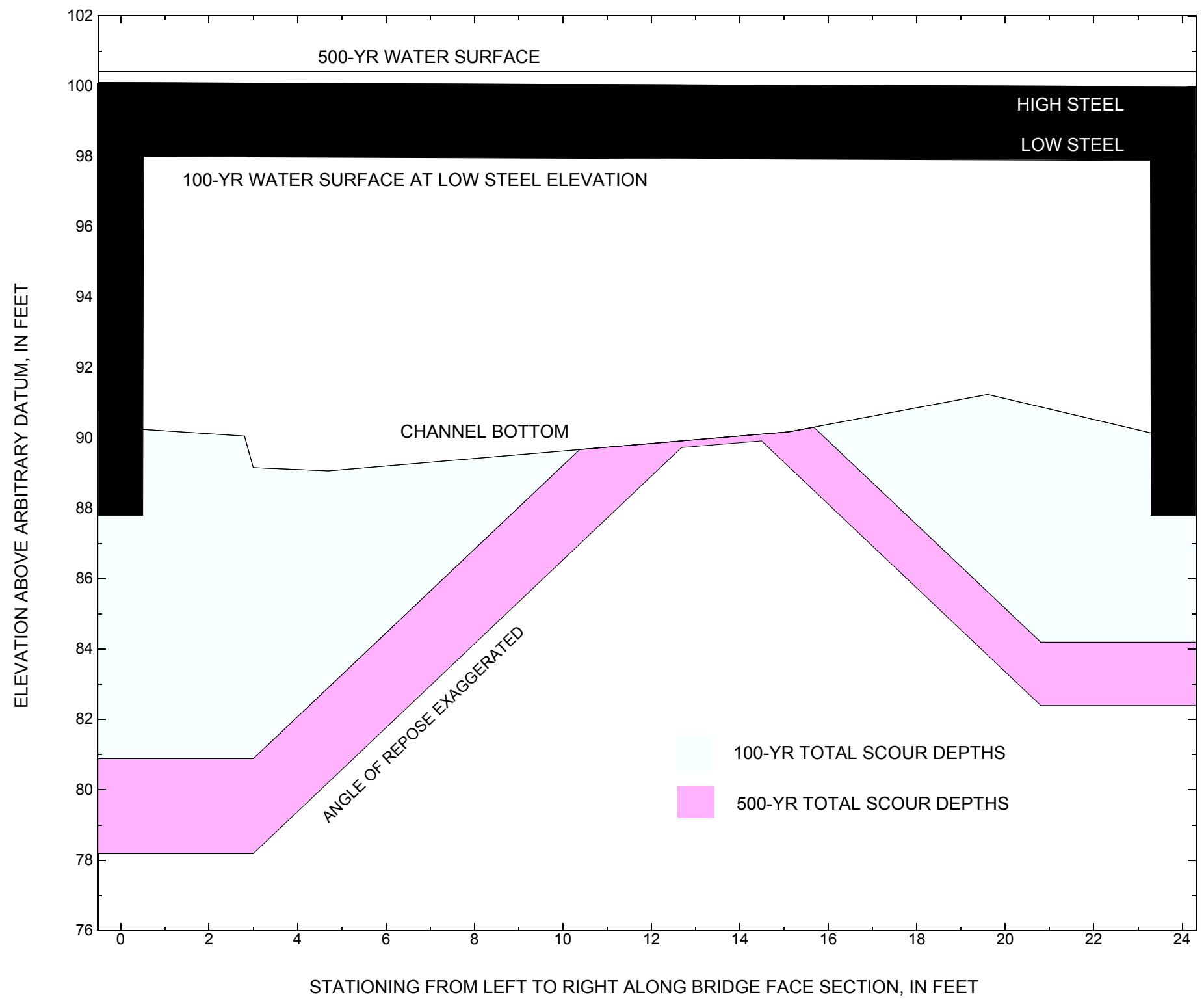

Figure 8. Scour elevations for the 100-yr and 500-yr discharges at structure BRIDTH00050032 on town highway 5, crossing the North Branch Ottauquechee River, Bridgewater, Vermont. 


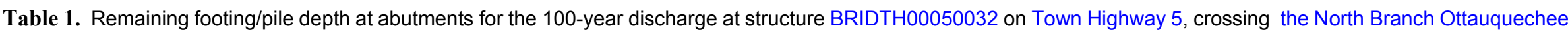
River, Bridgewater, Vermont.

[VTAOT, Vermont Agency of Transportation; --,no data]

\begin{tabular}{|c|c|c|c|c|c|c|c|c|c|c|c|}
\hline Description & Station $^{1}$ & $\begin{array}{l}\text { VTAOT } \\
\text { plans' } \\
\text { bridge seat } \\
\text { elevation } \\
\text { (feet) }\end{array}$ & $\begin{array}{l}\text { Surveyed } \\
\text { minimum } \\
\text { low-chord } \\
\text { elevation } \\
\text { (feet) }\end{array}$ & $\begin{array}{l}\text { Bottom of } \\
\text { footing } \\
\text { elevation } \\
\text { (feet) }\end{array}$ & $\begin{array}{c}\text { Channel } \\
\text { elevation at } \\
\text { abutment/ } \\
\text { pier }^{2} \\
\text { (feet) }\end{array}$ & $\begin{array}{l}\text { Contraction } \\
\text { scour depth } \\
\text { (feet) }\end{array}$ & $\begin{array}{l}\text { Abutment } \\
\text { scour } \\
\text { depth } \\
\text { (feet) }\end{array}$ & $\begin{array}{l}\text { Pier } \\
\text { scour } \\
\text { depth } \\
\text { (feet) }\end{array}$ & $\begin{array}{l}\text { Depth of } \\
\text { total scour } \\
\text { (feet) }\end{array}$ & $\begin{array}{l}\text { Elevation of } \\
\text { scour }^{2} \\
\text { (feet) }\end{array}$ & $\begin{array}{c}\text { Remaining } \\
\text { footing/pile } \\
\text { depth } \\
\text { (feet) }\end{array}$ \\
\hline \multicolumn{12}{|c|}{100 -yr. discharge is 1,320 cubic-feet per second } \\
\hline Left abutment & 0.0 & 500.5 & 98.0 & 88 & 90.3 & 0.0 & 9.4 & -- & 9.4 & 80.9 & -7 \\
\hline Right abutment & 23.8 & 500.9 & 97.9 & 88 & 90.0 & 0.0 & 5.8 & -- & 5.8 & 84.2 & -4 \\
\hline
\end{tabular}

1. Measured along the face of the most constricting side of the bridge.

2. Arbitrary datum for this study.

Table 2. Remaining footing/pile depth at abutments for the 500-year discharge at structure BRIDTH00050032 on Town Highway 5, crossing the North Branch Ottauquechee River, Bridgewater, Vermont.

[VTAOT, Vermont Agency of Transportation; --, no data]

\begin{tabular}{|c|c|c|c|c|c|c|c|c|c|c|c|}
\hline Description & Station $^{1}$ & $\begin{array}{l}\text { VTAOT } \\
\text { plans' } \\
\text { bridge seat } \\
\text { elevation } \\
\text { (feet) }\end{array}$ & $\begin{array}{l}\text { Surveyed } \\
\text { minimum } \\
\text { low-chord } \\
\text { elevation } \\
\text { (feet) }\end{array}$ & $\begin{array}{l}\text { Bottom of } \\
\text { footing } \\
\text { elevation } \\
\text { (feet) }\end{array}$ & $\begin{array}{c}\text { Channel } \\
\text { elevation at } \\
\text { abutment/ } \\
\text { pier }^{2} \\
\text { (feet) }\end{array}$ & $\begin{array}{l}\text { Contraction } \\
\text { scour depth } \\
\text { (feet) }\end{array}$ & $\begin{array}{l}\text { Abutment } \\
\text { scour } \\
\text { depth } \\
\text { (feet) }\end{array}$ & $\begin{array}{l}\text { Pier } \\
\text { scour } \\
\text { depth } \\
\text { (feet) }\end{array}$ & $\begin{array}{l}\text { Depth of } \\
\text { total scour } \\
\text { (feet) }\end{array}$ & $\begin{array}{c}\text { Elevation of } \\
\text { scour }^{2} \\
\text { (feet) }\end{array}$ & $\begin{array}{c}\text { Remaining } \\
\text { footing/pile } \\
\text { depth } \\
\text { (feet) }\end{array}$ \\
\hline \multicolumn{12}{|c|}{ 500-yr. discharge is 1,860 cubic-feet per second } \\
\hline Left abutment & 0.0 & 500.5 & 98.0 & 88 & 90.3 & 0.2 & 11.9 & -- & 12.1 & 78.2 & -10 \\
\hline Right abutment & 23.8 & 500.9 & 97.9 & 88 & 90.0 & 0.2 & 7.4 & -- & 7.6 & 82.4 & -6 \\
\hline
\end{tabular}

1. Measured along the face of the most constricting side of the bridge.

2. Arbitrary datum for this study. 


\section{SELECTED REFERENCES}

Arcement, G.J., Jr., and Schneider, V.R., 1989, Guide for selecting Manning's roughness coefficients for natural channels and flood plains: U.S. Geological Survey Water-Supply Paper 2339, 38 p.

Barnes, H.H., Jr., 1967, Roughness characteristics of natural channels: U.S. Geological Survey Water-Supply Paper 1849, 213 p.

Brown, S.A. and Clyde, E.S., 1989, Design of riprap revetment: Federal Highway Administration Hydraulic Engineering Circular No. 11, Publication FHWA-IP-89-016, 156 p.

Federal Highway Administration, 1983, Runoff estimates for small watersheds and development of sound design: Federal Highway Administration Report FHWA-RD-77-158

Federal Emergency Management Agency, 1980, Flood Insurance Study, Town of Bridgewater, Windsor County, Vermont: Washington, D.C., January 1980.

Froehlich, D.C., 1989, Local scour at bridge abutments in Ports, M.A., ed., Hydraulic Engineering--Proceedings of the 1989 National Conference on Hydraulic Engineering: New York, American Society of Civil Engineers, p. 13-18.

Hayes, D.C.,1993, Site selection and collection of bridge-scour data in Delaware, Maryland, and Virginia: U.S. Geological Survey Water-Resources Investigation Report 93-4017, 23 p.

Johnson, C.G. and Tasker, G.D.,1974, Progress report on flood magnitude and frequency of Vermont streams: U.S. Geological Survey Open-File Report 74-130, 37 p.

Laursen, E.M., 1960, Scour at bridge crossings: Journal of the Hydraulics Division, American Society of Civil Engineers, v. 86, no. HY2, p. 39-53.

Potter, W. D., 1957a, Peak rates of runoff in the Adirondack, White Mountains, and Maine woods area, Bureau of Public Roads

Potter, W. D., 1957b, Peak rates of runoff in the New England Hill and Lowland area, Bureau of Public Roads

Richardson, E.V., and Davis, S.R., 1995, Evaluating scour at bridges: Federal Highway Administration Hydraulic Engineering Circular No. 18, Publication FHWA-IP-90-017, 204 p.

Richardson, E.V., Harrison, L.J., Richardson, J.R., and Davis, S.R., 1993, Evaluating scour at bridges: Federal Highway Administration Hydraulic Engineering Circular No. 18, Publication FHWA-IP-90-017, 131 p.

Richardson, E.V., Simons, D.B., and Julien, P.Y., 1990, Highways in the river environment: Federal Highway Administration Publication FHWA-HI-90-016.

Ritter, D.F., 1984, Process Geomorphology: W.C. Brown Co., Debuque, Iowa, 603 p.

Shearman, J.O., 1990, User's manual for WSPRO--a computer model for water surface profile computations: Federal Highway Administration Publication FHWA-IP-89-027, 187 p.

Shearman, J.O., Kirby, W.H., Schneider, V.R., and Flippo, H.N., 1986, Bridge waterways analysis model; research report: Federal Highway Administration Publication FHWA-RD-86-108, 112 p.

Talbot, A.N., 1887, The determination of water-way for bridges and culverts.

U.S. Department of Transportation, 1993, Stream stability and scour at highway bridges, Participant Workbook: Federal Highway Administration Publication FHWA HI-91-011.

U.S. Geological Survey, 1966, Delectable Mountain, Vermont 7.5 Minute Series quadrangle map: U.S. Geological Survey Topographic Maps, Photoinspected 1983, Scale 1:24,000. 


\section{APPENDIX A: \\ WSPRO INPUT FILE}




\section{APPENDIX B: \\ WSPRO OUTPUT FILE}


WSPRO OUTPUT FILE

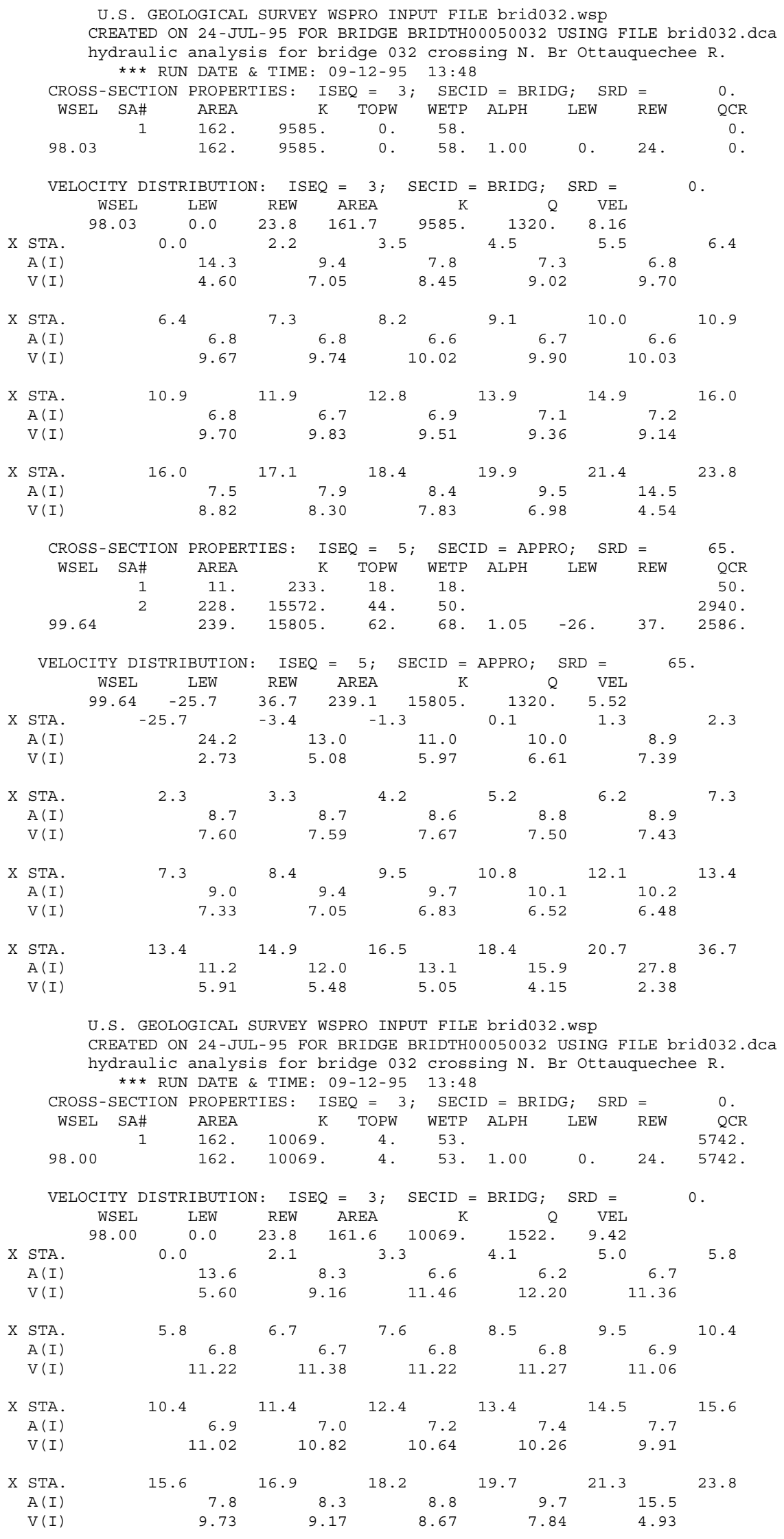


WSPRO OUTPUT FILE (continued)

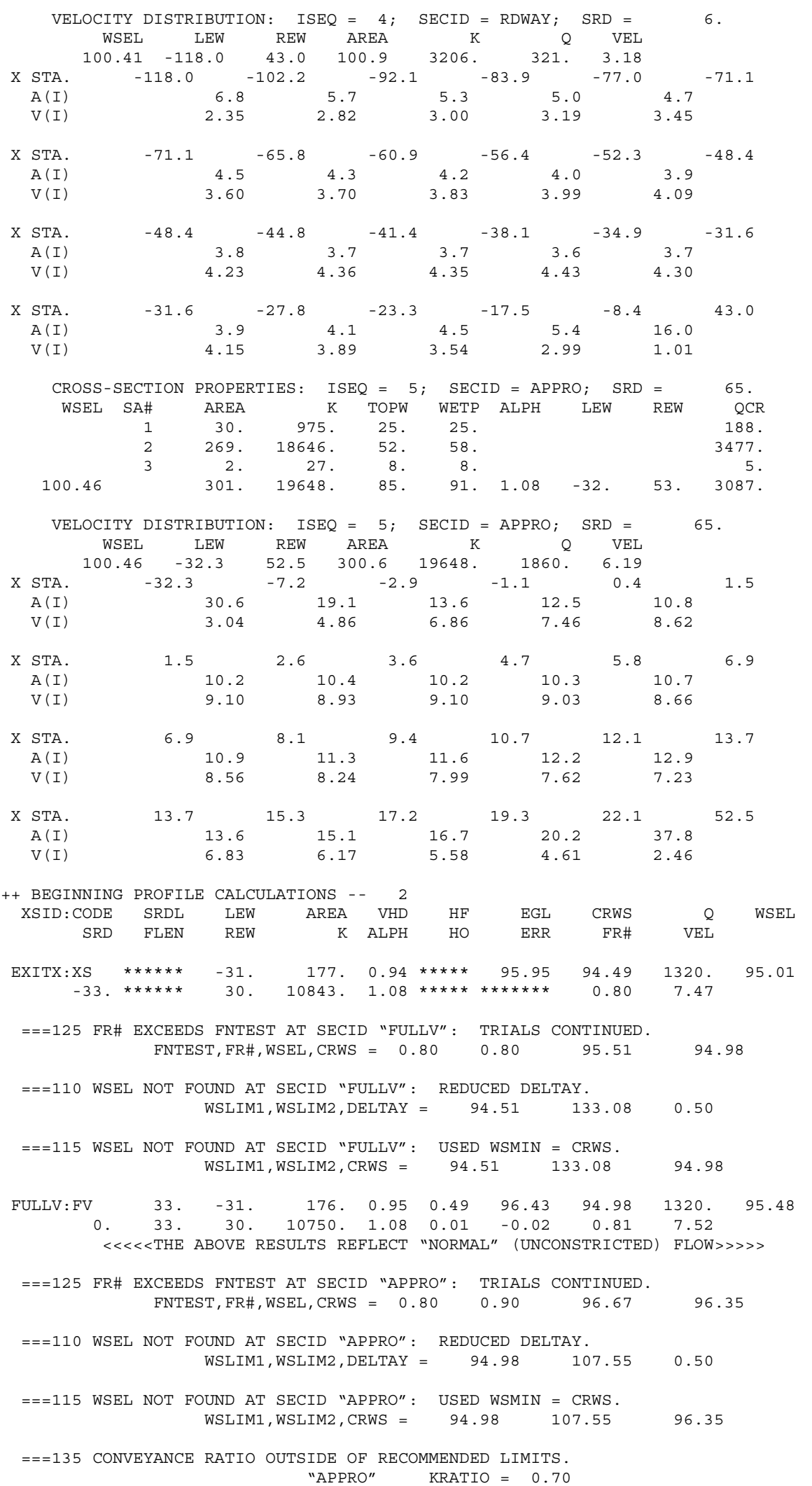

$$
\text { "APPRO" KRATIO }=0.70
$$

$\begin{array}{llllllllll}\text { APPRO: } \mathrm{AS} & 65 . & -6 . & 127 . & 1.68 & 1.40 & 98.34 & 96.35 & 1320 . & 96.66\end{array}$

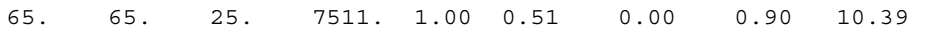
<<<<THE ABOVE RESULTS REFLECT "NORMAL" (UNCONSTRICTED) FLOW >>> 


\section{WSPRO OUTPUT FILE (continued)}

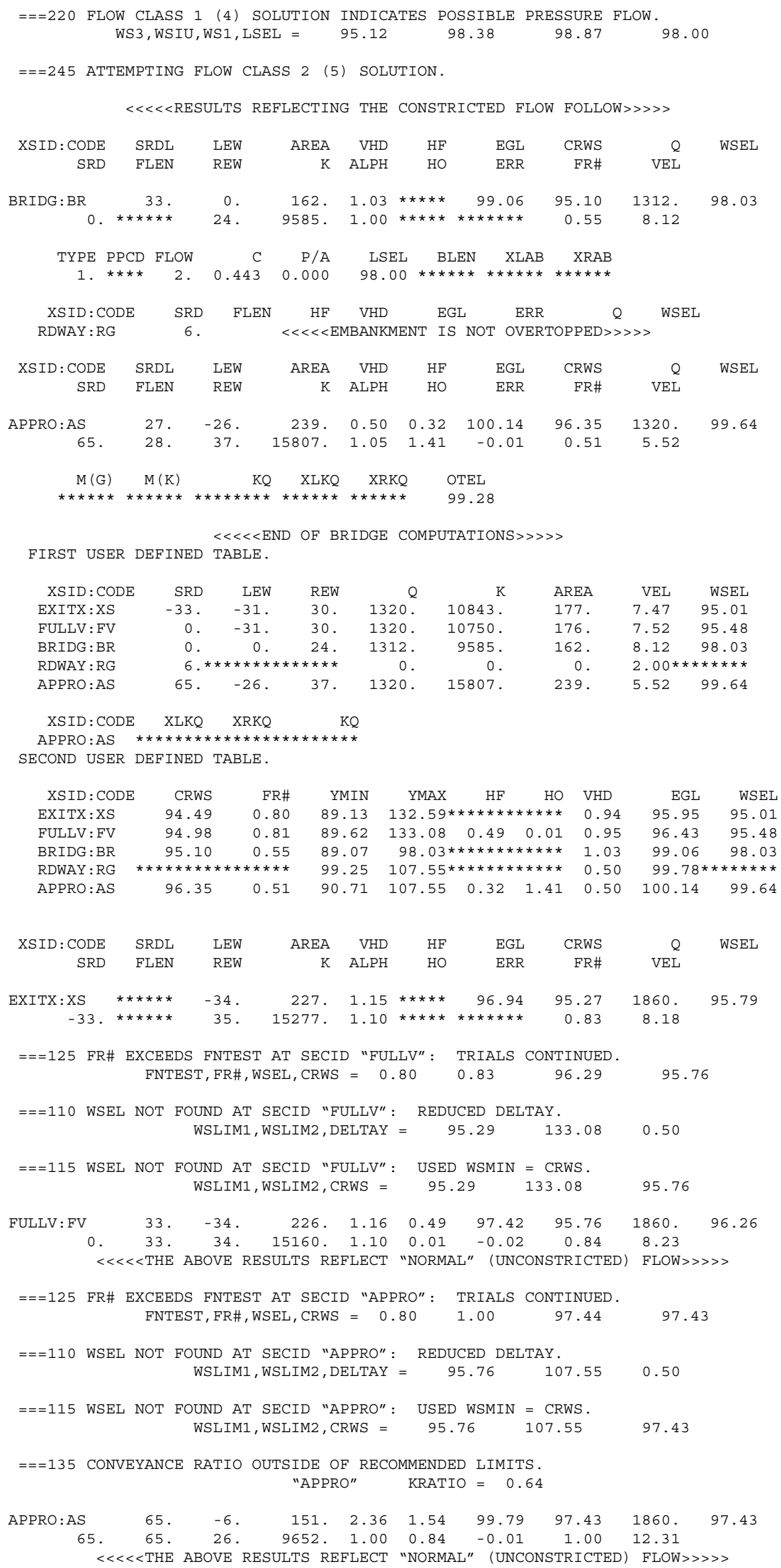




\section{WSPRO OUTPUT FILE (continued)}

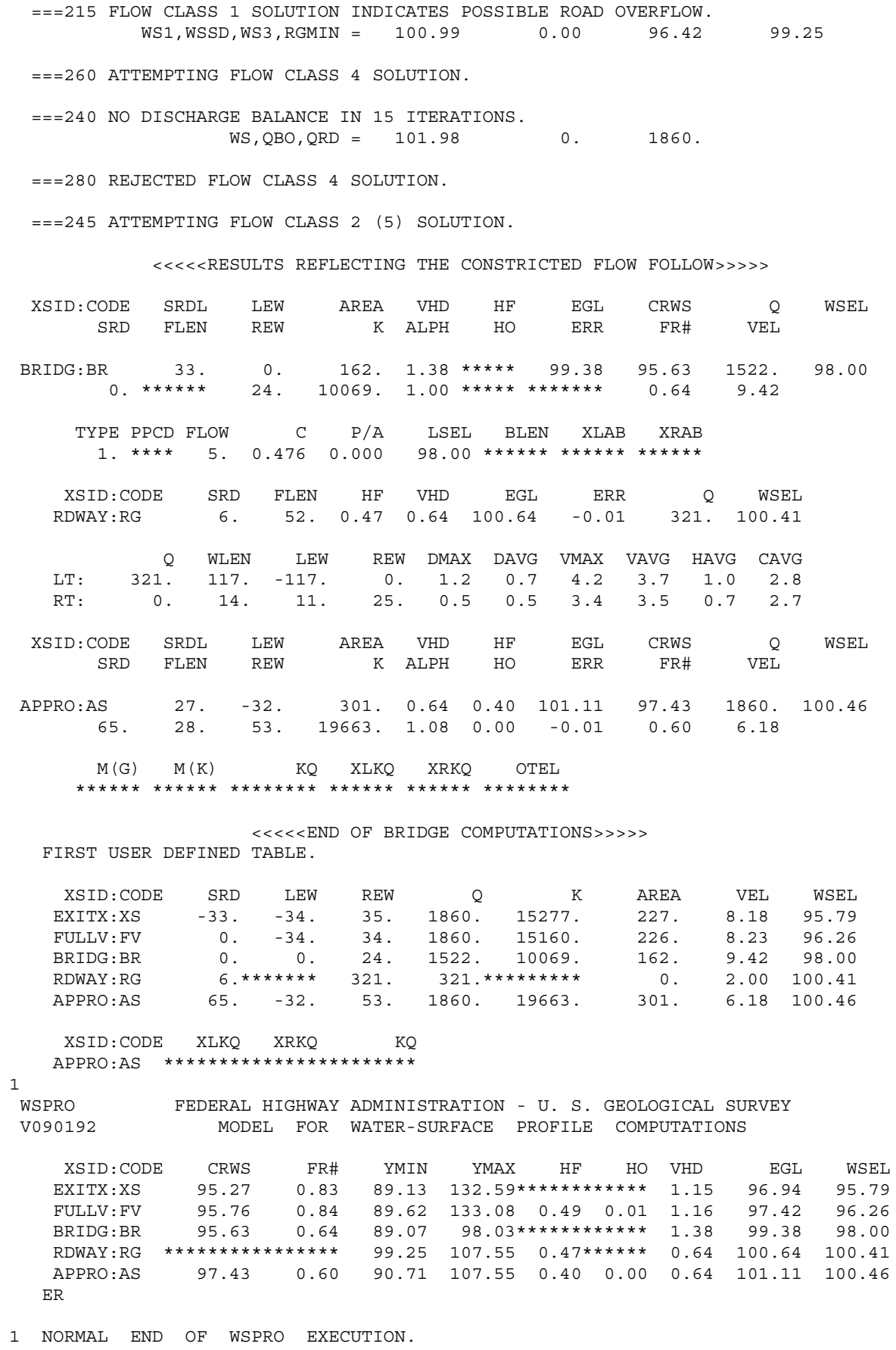




\section{APPENDIX C:}

\section{BED-MATERIAL PARTICAL-SIZE DISTRIBUTION}




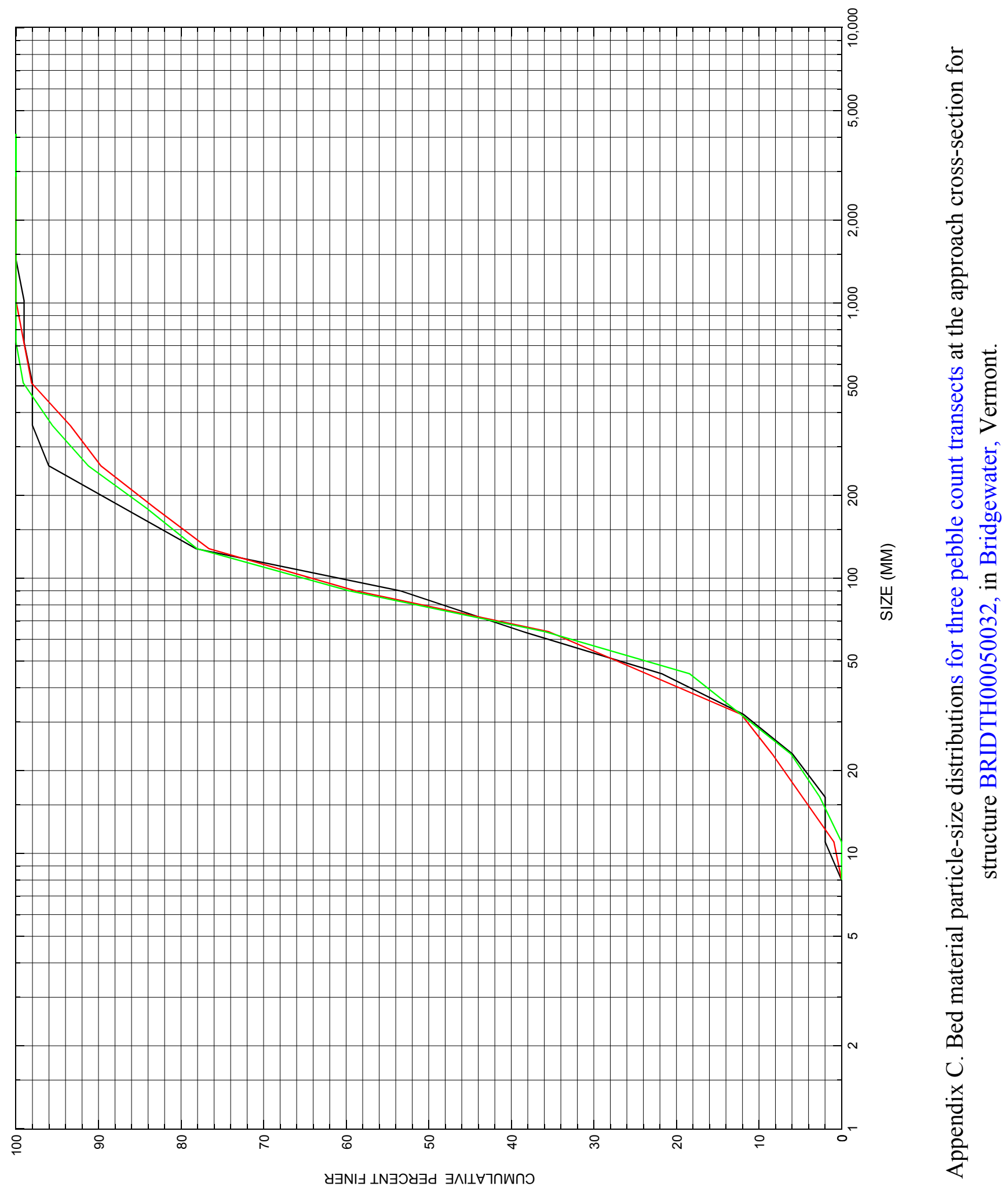




\section{APPENDIX D: \\ HISTORICAL DATA FORM}

